\title{
An Investigation of Cree Indian Domestic Fisheries in Northern Quebec
}

\section{FIKRET BERKES ${ }^{1}$}

\begin{abstract}
Domestic or subsistence fisheries of the eastern James Bay Cree. were studied, mainly in Fort George, by direct observation. These fisheries were characterized by large numbers of participants, low catches per day and per fisherman, but high catches per length of net used, as compared to commercial fisheries. Most stocks appear lightly utilized, but in the vicinity of larger settlements there is evidence that some stocks are overfished. The total catch may be increased by distributing the fishing effort more evenly over a larger area. Fish resource base of the region appears suitable for supporting local economic development with respect to recreational fisheries and native-run commercial fisheries for the local market, as well as maintaining the domestic fishery.
\end{abstract}

RESUME. On a étudié, par observation directe, principalement à Fort Georges, les types de pêche, familiales ou de subsistance. Les pêcheries sont caracterisées par le grand nombre de participants, la faiblesse des prises, par jour et par pêcheur, mais aussi par l'importance des prise par longueur de filet utilisé, en comparison avec la pêche commerciale. La plus grande partie des réserves paraît peu utilisée,mais dans les régions de colonies plus importantes, il est évident qu'on a trop pêché de poissons. On peut également accroitre la prise totale, en repartissant l'effort de pèche sur une plus grande étendue. Les ressources de la pèche, base de la région, apparaissent suffisantes pour supporter un developpement économique local, en respectant le pêche de distraction et la pêche commerciale des indigènes pour le marché local, tout en maintenant la pèche familiale.

Traduit par Alain de Vendegies, Aquitaine Co. of Canada Ltd.

\section{INTRODUCTION}

"Domestic fishing" refers to the capture of fish for local, non-commercial purposes. The term is used interchangeably here with "subsistence fishing", the use of which is more prevalent in anthropology and economics and which tends to emphasize the self-sufficiency aspect of the operation. The catch may be generally reserved for family consumption or may become an input into the community-wide food exchange system.

Domestic fisheries of registered native peoples in Canada are not subject to government regulation. The conduct of these fisheries has developed, through practical experience over many generations, along different lines than those of commercial fisheries. It appears that there is some subsistence fishing in most, if not all, communities of northern native peoples in Canada. Small-scale domestic fisheries no doubt exist in the South as well, but perhaps only in the North are these fisheries quantitatively large in comparison to commercial fisheries. For example, in northern Quebec, Power and Le Jeune (1976) estimated that domestic fisheries take some $377,000 \pm 141,000 \mathrm{~kg}$ per year, as compared to some $30,000 \mathrm{~kg}$ taken by sport fishermen at licensed clubs. The domestic catch was estimated to be greater than the combined

\footnotetext{
'Institute of Urban \& Environmental Studies Brock University St. Catharines, Ontario L2S
} 3A1 
catch of sport and commercial fisheries, but nevertheless two orders of magnitude less than the biological potential of the area. There are small commercial fisheries in the Ungava Bay area, but none in the James Bay area.

Berger (1977: 117) commented on the lack of data on domestic fisheries in the North. As explained by Regier (1976), up until recent years, domestic and small-scale fisheries were perceived at senior policy levels as a very minor component within the complex of renewable resources and their contribution to the total Canadian economy was thought to be insignificant. As these fisheries were not controlled, surveyed or monitored in any way, no catch statistics were kept and no research undertaken, except at a general descriptive level (for example, Helm and Lurie, 1961; Rogers, 1972).

Recently, however, there has been renewed interest and much discussion on the viability of the renewable resource sector in the North. It has been argued on the one hand that a strong local economy based on renewable resources is necessary if northern native peoples and their culture are to survive the onslaught of industrial development in the North (Berger, 1977: 3; for an earlier discussion of a similar view, Freeman, 1969). On the other hand, it has been argued that the renewable resource sector in the North is static or declining and therefore not capable of providing employment for an expanding population (Stabler, 1977). Further, the data base upon which Berger drew his conclusions has been seriously questioned (Bliss, 1978). Biological factors relevant to this argument are relatively well studied with respect to big game, fur animals and waterfowl, but poorly known with respect to fish, which Berger (1977: 36) suggested to be the best prospect for increased food production in the North.

One basic issue is whether the local resource harvest can provide sufficient quantities of food for northern native communities, given the present patterns of settlement. Additional issues concern the assessment of the resource with respect to commercial fishery possibilities for the local market, recreational fisheries, and processing and service industries associated with these.

The purpose of the present paper is to explore these issues in light of information available on the prosecution of domestic fisheries in the eastern James Bay area, northern Quebec, their historical development and trends, the catch in relation to biology of the species, and levels of yield. Particular attention is given to biology and productivity of anadromous (sea-run) coregonid stocks, whitefish and cisco, on which published information is scarce.

\section{Methods of Study}

As a gray, interdisciplinary area between biological and social sciences, there are no satisfactory precedents of methodology for the investigation of subsistence fisheries. The following methodology was developed, and some of the results have already been published elsewhere (Berkes, 1977). The basic research technique has been to participate in fishing activities. This conforms with Cree practices which favour learning by doing, rather than by asking questions. Data were collected by sampling the catch of Cree fishermen. The 
investigator travelled with fishermen fishing on their own schedules, by traditional methods, and in traditional locations.

In all, 21 fishermen in Fort George and 10 in Eastmain contributed to the study. From 1975 to 1978 inclusive, 344 sets of catch records were taken in Fort George and 46 in Eastmain (1977 only). According to questionnaire data collected in Fort George, the number of men over 18 years reporting a catch of fish for the year 1974-75 was 237 or about $65 \%$ of all men over 18 (JBNQNHRC, 1976, Appendices). Thus the present study covered about $10 \%$ of all fishermen in the community. In terms of the total annual community catch in Fort George, assuming that questionnaire studies have produced reliable estimates (Weinstein, 1976; JBNQNHRC, 1976), the present study sampled 1 to $2 \%$ in each of the years covered. Details of seasonal coverage, the number of trips and the number of fishermen per sampling period for 1975 and 1976 are given in Berkes (1977).

Two sets of data were collected simultaneously. Catch data included information on methods, gear, frequency of net setting, fishing time and locations of catch. Biological data included catch composition by numbers and weight of different species, lengths and maturity of individual fish, and scale samples for age determination. Fish weights represent whole (round) weights. Conducting biological research while being guests of Cree fishermen has some drawbacks: catch records exclude one group of fish, sculpins (Myoxocephalus spp., mainly M. quadricornis) which could not be measured or weighed because they were not kept by the fishermen but killed and immediately thrown out, as these fish fouled up the nets and were considered inedible.

Field studies were carried out in Fort George and, to a lesser extent, in Eastmain. Information on local practices was obtained also in communities of Paint Hills (Wemindji), Great Whale, Rupert House and Mistassini. Supporting material used in this paper, unless otherwise referenced, is based on the author's unpublished field notes from these communities.

\section{PROBLEMS IN ESTIMATING THE TOTAL COMMUNITY CATCH}

Fort George is a predominantly Cree Indian community (pop. about 1,600 in 1975) located on the estuary of La Grande River which empties into James Bay. Eastmain is a smaller Cree village with about one-fifth the population of Fort George. Locations of these two communities and others mentioned in the text are shown in Figure 1.

In Fort George, most families do some fishing in the course of a year, as they also do some hunting. Thus, the number of production units in the domestic fishery nearly equals the number of family units. Each group has its own traditional or favourite fishing areas, thus, the number of fishing spots may be large and dispersed over a huge area. Further, much of the catch may be consumed immediately in fishing camps. Thus, field recording of the entire fish catch in a community the size of Fort George would be impossible.

In the James Bay area, considerable work has been done since 1972 to record the catch of fish and wildlife by the questionnaire method. Weinstein 
(1976) estimated a total Fort George community annual harvest of 171,500 fish in $1973 / 74$, the equivalent of $53,930 \mathrm{~kg}$ potential food weight. This represented about one-quarter of the total food weight from the bush. These findings were generally confirmed for $1975 / 75$ by a less detailed study conducted by JBNQNHRC (1976). Comparisons of field data with questionnaire results show that these results are within the expected order of magnitude (JBNQNHRC, 1976, Appendix V-I).

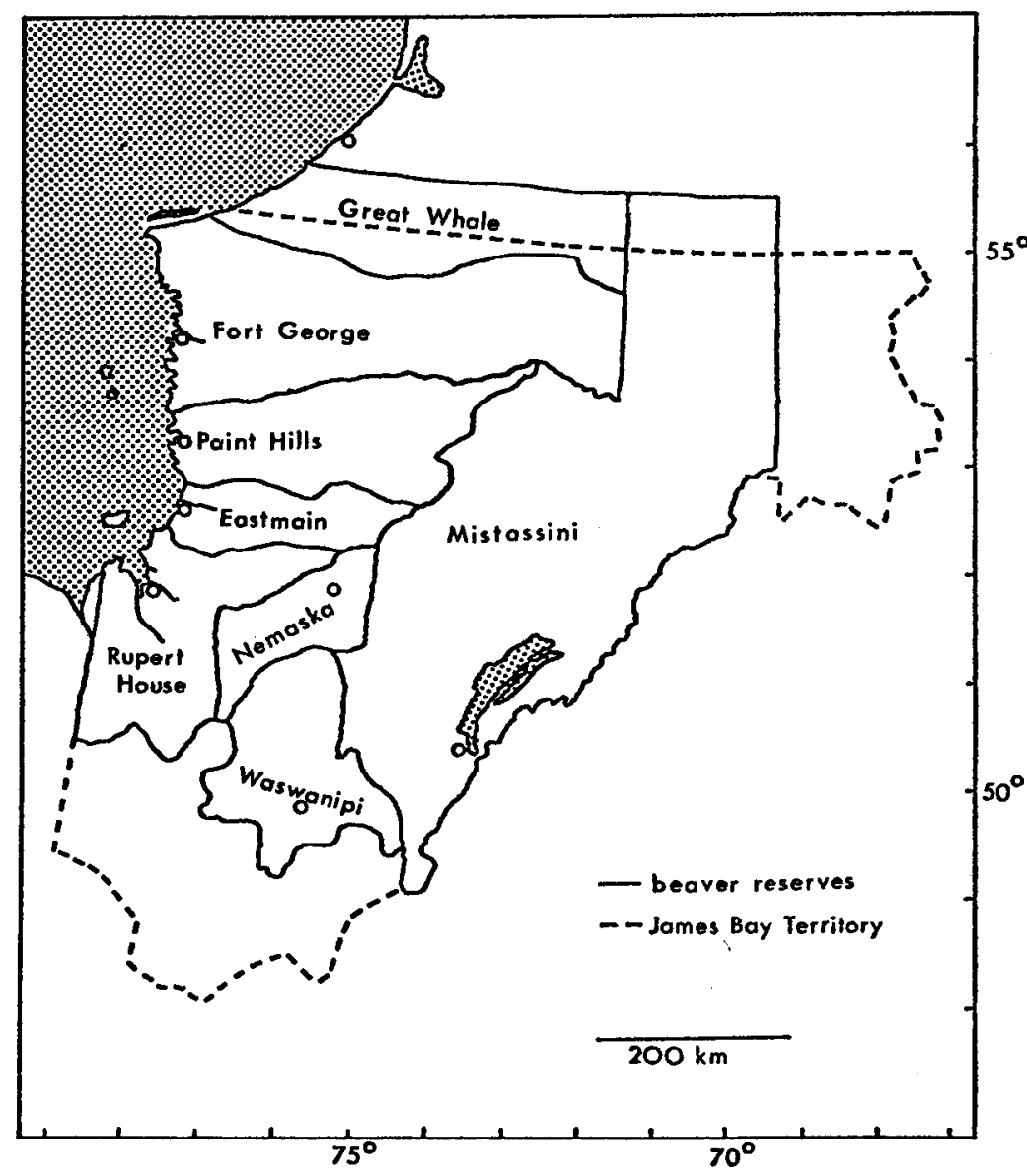

FIG. 1. Extent of trapping areas of eastern James Bay Cree bands and the James Bay Territory, as defined by the Agreement. To the north of the Territory, is the Inuit area of primary interest.

A degree of uncertainty is introduced, however, by the presence of year-to-year variations in fishing success by seasons in fisheries in the Fort George area. Table 1, based on information provided by Cree fishermen, gives an indication of these fluctuations. Three component fisheries are said to be variable: the August First Rapids fishery, the pre-freezeup fishery, and the Black's Island (south branch of estuary) ice-fishery. These variations seem to be related to such environmental variables as water levels, temperatures, 
TABLE 1. Annual and seasonal variation in fishing success, near fort George domestic fisheries, according to information from Cree fishermen (two major informants; verified for different years by 4 to 10 others).

\begin{tabular}{|c|c|c|c|c|c|c|c|}
\hline Component fisheries & 1972 & 1973 & 1974 & 1975 & 1976 & 1977 & 1978 \\
\hline Spring, estuary \& lower river & $\mathbf{x x}$ & $\mathbf{x x}$ & $\mathbf{x x}$ & $\mathbf{x x}$ & $\mathbf{x x}$ & $\mathbf{x x}$ & $\mathbf{x x}$ \\
\hline Summer, lower river & $\mathbf{x}$ & $\mathbf{x}$ & $\mathbf{x}$ & $\mathbf{x}$ & $\mathbf{x}$ & $\mathbf{x}$ & $\mathbf{x}$ \\
\hline August, first rapids of La Grande & $\mathrm{x}$ & $\mathrm{x}$ & $\mathrm{x}$ & $\mathrm{xx}$ & $\mathrm{x}$ & $\mathbf{X X X}$ & $\mathbf{x x}$ \\
\hline October, pre-freeze-up, estuary & & & & $\mathrm{xx}$ & $\mathbf{x x x}$ & $\mathbf{x x}$ & $\mathbf{x x}$ \\
\hline Black's Island ice-fishery & $\mathbf{x x x}$ & $\mathbf{x x x}$ & $\mathrm{xx}$ & $\mathbf{x}$ & $\mathrm{xx}$ & $\mathbf{x}$ & $\mathrm{x}$ \\
\hline
\end{tabular}

$\mathbf{x x x}$ - successful

$\mathrm{xx}$ - moderate

$\mathrm{x}$ - poor

wind, speed and date of freezeup, but relevant data are not available. By contrast, the spring and summer fisheries at Fort George, other coastal fisheries away from Fort George and lake fisheries are said not to show clear year-to-year variability.

Parts of Table 1 were tested by using field data on catch per net set. It has been shown that the length of time a gillnet has been left in the water is not correlated with the size of the catch, hence, catch per net set is an appropriate measure of catch per unit of effort (Berkes, 1977). In the October fishery, LaGrande estuary, the 1976 catch of $10.2 \mathrm{~kg}$ per net set is significantly different ( $p<0.01$ by t-test) from either the 1975 catch, $4.3 \mathrm{~kg}$, or the 1977 catch, $4.1 \mathrm{~kg}$. The First Rapids fishery in 1978 gave a yield of $91 \mathrm{~kg}$ per trip, as compared to $90 \mathrm{~kg}$ in 1977 but only $54 \mathrm{~kg}$ in 1975 . In the ice-fishery, there were no significant differences in the mean catch per net set $(5.8 \mathrm{~kg}$ in 1975 , $5.3 \mathrm{~kg}$ in 1976 and $5.0 \mathrm{~kg}$ in 1977) but the 1976 fishery gave greater overall yields than the other two because it lasted longer. In other component fisheries, there were no significant differences. For example, the Capsaouis River estuary spring fishery for whitefish and brook trout provided similar harvests in 1975 and $1976,9.5$ and $9.7 \mathrm{~kg}$ per net set.

A second reason for the year-to-year variation is the abundance or lack cereof of other country game. Fishing is only one component of an animal narvesting system, and the availability of snowshoe hares and the productivity of the seasonal goose hunt, for example, appear to have a bearing on the fish harvest. Weinstein (1976) presented some data in support of this general phenomenon. In 1971/72, a good year for hare, an estimated 22\% of the Fort George community wild food harvest by weight came from this species. In 1973/74, however, the hare population cycle was on a downward trend, and hare provided only $5 \%$. Weinstein (1976: 113) speculated that an apparent increase in the waterfowl and fish harvest from 1971/72 to 1973/74 may have compensated for the decrease in the hare catch.

Year-to-year variations of this nature make it very difficult to estimate the total catch of a domestic fishery. Certainly a great deal of caution should be exercised in using an estimate based on fishing activities of only part of the year and part of the harvesting area. 
DESCRIPTION OF THE FISHERY: PRESENT AND HISTORICAL

There is no commercial fishing at present in any part of the region within Cree trapping areas. Harvest from domestic fisheries is used almost exclusively within the community. Non-native sports fishing in the region is of minor importance at present (Power and Le Jeune, 1976), except in the immediate vicinity of hydroelectric power project construction and other development areas. See Penn (1975) for description of the hydro project and the court case and JBNQA (1975) for details of the settlement between native groups and governments.

James Bay coast north of Eastmain is low-lying and very indented. Fort George fishermen navigate this coast in Rupert House-style, 22 to 24-ft, u-bottomed freighter canoes with 20 to 45 HP outboard motors. Smaller freighter canoes are used in Eastmain and in navigable inland waters. Paddle canoes are used in smaller waterways. Fishing is usually a family activity, combined with hunting and berry-gathering activities at traditional harvesting sites which often, but not necessarily, correspond to traditional trapping areas of family groups.

Most fishing on the coast is carried out with multifilament nylon gillnets of $2 \frac{1}{2}, 3,31 / 2,4$, and 5 inch mesh, stretched measure $(63.5 \mathrm{~mm}, 76.2 \mathrm{~mm}, 88.9$ $\mathrm{mm}, 101.6 \mathrm{~mm}$ and $127.0 \mathrm{~mm}$ respectively). In Fort George coastal fisheries, these nets are $51 \pm 4 \mathrm{~m}$ long and about $1.3 \mathrm{~m}$ wide when set in water. Each fisherman employs $1.9 \pm 1.2$ (mean and standard deviation of all recorded net sets) at one time. The range is one to five nets.

Fishing activity does not extend out to open water. Netting is confined to areas not deeper than about $3 \mathrm{~m}$. The area within $15 \mathrm{~km}$ of Fort George is harvested on a day-trip basis. Fishermen harvesting areas outside of a $15 \mathrm{~km}$ distance camp out overnight, often staying for several days at a location (Table 2). Smaller mesh nets are used in the Fort George area and larger mesh sizes further away (Table 3). Within $15 \mathrm{~km}$ of Fort George, Cree fishermen use mainly $2 \frac{1}{2}$ inch nets, but a mix of larger mesh sizes elsewhere. This spatial patterning of net size usage is related to the exploitation of cisco near Fort George, but mainly of whitefish elsewhere, as discussed in detail in Berkes(1977). The largest mesh size, 5 inch, was recorded in use only in Cape

TABLE 2. Number of net sets recorded during day trips from the settlement and during overnight trips. A "net set" is defined as the use of one (approximately) $50 \mathrm{~m}$ gillnet once, from the time it is placed in water to the time it is checked.

Number of net sets

\begin{tabular}{c} 
Number of net sets \\
\hline Day trips $\quad$ Ovemight trips
\end{tabular}

Within $15 \mathrm{~km}$ radius of F. George 
TABLE 3. Number of times that a net of a particular mesh-size was employed in the Fort George area (within $15 \mathrm{~km}$ of settlement) and away from Fort George (outside a $15 \mathrm{~km}$ radius from the settlement).

\begin{tabular}{|c|c|c|c|c|c|}
\hline & & gillr & esh si & ches & \\
\hline & $21 / 2$ & 3 & $31 / 2$ & 4 & 5 \\
\hline Fort George area & 262 & 81 & 12 & 0 & 0 \\
\hline Away from Fort George & 4 & 16 & 20 & 38 & 14 \\
\hline
\end{tabular}

Jones area lakes. The small mesh size is used in the immediate area of other coastal Cree villages as well. In inland communities, however, 4 inch nets are used predominantly in all areas. Nets are checked usually once a day when fishermen are operating out of the settlement (Fort George and Eastmain), twice a day from fishing camps along the coast. In winter ice-fishing in lakes, nets are checked only once a week or so. In each case, the duration of the net set seems related to a threshold after which the catch does not increase (Berkes, 1977).

Substantial amounts of fish are caught also by other methods: angling for predatory species such as pike by the use of either rod-and-reel or traditional set lines (Lebuis, 1971: 79), and by "seining". The seining method is used at the first set of rapids of several major rivers. At Fort George, the seine is a gillnet drawn by hand in rocky coves at the foot of rapids, scooping fish which are milling in the eddy of the cove.

Fish caught in excess of immediate needs of the family and relatives may be sun-dried, smoked or frozen whole. Smaller communities such as Eastmain and Paint Hills have communal freezers. In Fort George, many families have their own. Much of the surplus catch is given away. These exchanges tend to be mutual, but there is no bartering as such. Local sale of fish is uncommon but does happen with rare and valuable species, for example, arctic char in Fort George and sturgeon in Paint Hills. These were privately sold or marketed through the village cooperative store.

\section{Historical}

Fish have always been an important staple in the subsistence economy of the area, and fishing methods used in the past appear to be similar to those today. Earliest biological investigations of James Bay fisheries (Melville et al., 1915) recorded the use of gillnets by the Crees, smaller mesh sizes on the coast and larger ones inland. Some investigators have claimed that gillnets were used by Indians of the Great Lakes and St. Lawrence areas in pre-contact times (Moussette, 1973). It is not clear, however, whether gillnetting was an aboriginal technique in eastern James Bay as well. Older informants reported knowledge of gillnets made of willow root (Fort George) and strips of caribou skin (Rupert House). Twine gillnets were in use in Eastmain in the 1700's, and twine has been available through the Hudson's Bay Company since the early 1700 's (Ornstein, pers. comm.).

Multifilament gillnets were first introduced around the late 1950's in Fort George and 1963/64 in Mistassini (Speers, pers. comm.). Before that, people 
made their own nets; some old people still do, for example in Eastmain. By and large, nets are now bought from the store by the span (Fort George) or by the pound (Mistassini), but floats, line and sinkers are locally added. Details of design of nets may be found in LeBuis (1971: 57), and some of the techniques in Rogers (1973: 60) and Johnson (1975: 236).

The seining technique also appears to be old. Description of the method by Melville et al. (1915: 22) is identical to the present practice. One fishing technique that has become less common over the years is the spearing or scooping of fish in stone weirs (traps) at narrow points of rivers. Kerr (1950: 193) described its use in Rupert's House, and traps are still being used as of 1978 on the Rupert River for whitefish. In Fort George, some traps may still be seen, for example, at a location south of Fort George, although they are not used today. North of Fort George the Inuit of Great Whale use a stone weir for catching arctic char in Richmond Gulf. Cree of Waswanipi occasionally practice spearing of large sturgeon, but no fish traps are used.

\section{Quantitative Importance of Fish}

The quantitative importance of fish in the eastern James Bay Cree subsistence economy probably fluctuated a great deal over the past century. In the early part of the century, when first the Hudson Bay herd of caribou (Elton, 1942: 378) and later beaver disappeared, fish probably became a crucially important food item. Furthermore, sled dogs did not become common on the area, at least inland, until 1900-1910. This must have increased the requirement for fish. According to various informants, dependence on fish was particularly acute in the 1940 's when fur prices collapsed. Since the 1940's and 1950's, beaver, waterfowl and, more recently, caribou populations have all increased, reducing the dependence on fish. This trend was accentuated in the 1960's with the replacement of sled dogs by snowmobiles.

Many authors identify fish as a backup or staple resource (Feit, 1973). This seems to hold for much of the North. Rogers and Black (1976) described a northern Ontario Ojibwa group which is said to have lived almost entirely off fish and small game between 1880 and 1920 . In the James Bay area as well some information suggests that there has been a significant change in dependence on fish resources. Rogers (1963) estimated that fish provided 53\% and 50\% of bush food of some hunting groups in Mistassini in 1912/13 and $1913 / 14$, respectively. In 1953/54 fish accounted for $26 \%$ of the catch, from fall to spring months (Rogers, 1963). This figure is similar to the findings of recent detailed investigations based on community-wide questionnaire studies. According to the study of the James Bay and Northern Quebec Native Harvesting Research Committee (JBNQNHRC, 1976) the total edible bush food harvest was $527 \mathrm{~g}$ per person per day in Mistassini in 1974/75, of which fish accounted for $25 \%$.

Importance of fish has fluctuated over the years in relation to availability of alternative resources. No doubt it has also varied in relation to population size, availability of new harvesting technology and disposable income. Tools have changed, but the basic techniques have not changed much. 
TABLE 4. Numbers of fish caught in the domestic fisheries of Fort George (La Grande Estuary) and Eastmain, as compared to results of biological surveys in the same waters. Biological data from Kidd et al. (1975, p. 14 and 19), data on domestic fishery, this study, supplemented with unpublished Environment Canada data from 1975 for Eastmain.

Lower La Grande River and estuary domestic fishery biological survey $(1975,1976,1977) \quad(1973,1974)$
Lower Eastmain River and estuary $\begin{array}{cc}\text { domestic fishery } & \text { biological survey } \\ (1975,1977) & (1973,1974)\end{array}$

\begin{tabular}{|c|c|c|c|c|c|c|c|c|c|}
\hline cisco & Coregonus artedii & 3,845 & $(67.3 \%)$ & 2,735 & $(50.3 \%)$ & 409 & $(50.8 \%)$ & 1,662 & $(51.6 \%)$ \\
\hline whitefish & Coregonus clupeaformis & 527 & $(9.2 \%)$ & $(467$ & $(8.6 \%)$ & 290 & $(36.0 \%)$ & 616 & $(19.1 \%)$ \\
\hline damaged Coregonus & & 82 & $(1.4 \%)$ & - & - & 20 & $(2.5 \%)$ & 43 & $(1.3 \%)$ \\
\hline round whitefish & Prosopium cylidraceum & 35 & $(0.6 \%)$ & 245 & $(4.5 \%)$ & - & - & 1 & - \\
\hline brook trout & Salvelinus fontinalis & 191 & $(3.4 \%)$ & 88 & $(1.6 \%)$ & 21 & $(2.6 \%)$ & 55 & $(1.7 \%)$ \\
\hline pike & Esox lucius & 13 & $(0.2 \%)$ & 22 & $(0.4 \%)$ & 6 & $(0.7 \%)$ & 114 & $(3.5 \%)$ \\
\hline walleye & Stizostedion vitreum & 92 & $(1.6 \%)$ & 15 & $(0.3 \%)$ & 12 & $(1.5 \%)$ & 259 & $(8.0 \%)$ \\
\hline $\operatorname{cod}$ & Gadus ogac & 35 & $(0.6 \%)$ & 84 & $(1.6 \%)$ & - & - & - & - \\
\hline burbot & Lota lota & 1 & - & 21 & $(0.4 \%)$ & 1 & $(0.1 \%)$ & 3 & - \\
\hline white sucker & Catostomus commersoni & 55 & $(1.0 \%)$ & 4 & - & 7 & $(0.9 \%)$ & 28 & $(0.9 \%)$ \\
\hline longnose sucker & Catostomus catostomus & 827 & $(14.5 \%)$ & 1,758 & $(32.3 \%)$ & 37 & $(4.6 \%)$ & 381 & $(10.8 \%)$ \\
\hline sturgeon & Acipenser fulvescens & - & - & 1 & - & - & - & 20 & $(0.6 \%)$ \\
\hline yellow perch & Perca flavescens & - & - & - & - & 2 & $(0.2 \%)$ & 42 & $(1.3 \%)$ \\
\hline \multicolumn{10}{|l|}{ Other species } \\
\hline sculpins & & \multicolumn{2}{|c|}{$\begin{array}{l}\text { (caught but } \\
\text { not kept) }\end{array}$} & 998 & (3 species) & - & - & 54 & (1 species) \\
\hline forage species & & - & - & 3,122 & (9 species) & - & - & 632 & (9 species) \\
\hline
\end{tabular}




\section{SPECIES COMPOSITION OF HARVEST}

Table 4 shows species composition in lower river and adjacent marine waters of LaGrande and Eastmain rivers. For comparison with the domestic fishery, results of Environment Canada's biological surveys (Kidd et al., 1975) are also given; these samples were obtained with experimental gillnets, $11 / 2$, $21 / 2,31 / 2,41 / 2$, and $51 / 2$ inch mesh. Cree catches were mostly with $21 / 2$ inch gillnets at Fort George (Table 3 ) and in the order of decreasing importance, 3 , $21 / 2,31 / 2$ and 4 inch gillnets at Eastmain.

Of 23 species of fish recorded by biological surveys in Fort George and 21 in Eastmain, the domestic fishery took only 10 and 9 species, respectively. This difference is mainly due to the presence of forage species caught by the smaller mesh sizes used in biological surveys. If forage species and sculpins are excluded from the calculation of percentages, then the species compositions in the two sets of data are similar (differences not significant, p> .05 by paired t-test). For example in Eastmain $51.6 \%$ of the biological survey catch and $50.8 \%$ of the domestic fishery catch consisted of cisco.

There are, however, some differences between the two sets of percentages. If it may be assumed that the biological survey results provide baseline figures on species composition, then deviation from these indicates selectivity.

In Fort George, the domestic fishery caught relatively more of cisco and brook trout, and relatively less of longnose sucker and round whitefish. These differences are explainable on the basis of Cree fishermen's (a) mesh size selectivity, and (b) deliberate selection based on knowledge of species distributions. The $2 \frac{1}{2}$ inch net selectively catches cisco (Berkes, 1977), therefore its prevalent use near Fort George (Table 3) maximizes cisco catches. Brook trout (sea-run form) is relatively rare in LaGrande estuary but highly prized by the Cree. Selectivity for brook trout probably indicates a knowledge of seasonal distributions of this species. Strong negative selectivity for longnose suckers is apparent from Table 4. Used mainly for dog food, this sucker is the most abundant fish in the lower LaGrande during its early summer run (mid-June to early July) in the estuary. Most Cree fishermen avoid it by not fishing in its area and season of abundance. Round whitefish, on the other hand, is an acceptable, even favoured, food species but it is small, very few specimens exceeding $25 \mathrm{~cm}$ length, and therefore not retained by Cree nets.

Selectivity of the Cree fishery at Fort George, while explainable on the basis of known Cree food preferences and biology of the species, may still be an artifact of sampling in different years. For this reason, it is important to repeat the same analysis with the Eastmain fishery, even though sample sizes are smaller. Here, again the domestic fishery caught relatively more of whitefish and less of longnose suckers. Selectively more of brook trout was caught but the sample size was small. Apparent negative selection for pike and walleye is probably an artifact of lack of spring samples for the Eastmain domestic fishery. The explanation for relatively more whitefish is that mesh sizes of 3 and $3 \frac{1}{2}$ inch, preferentially used at Eastmain, select for whitefish 
and not for cisco (Berkes, 1977). In general, therefore, apparent selectivity in both fisheries for favoured species, and apparent negative selectivity for undesirable species does seem real.

Another important feature of these domestic fisheries is the relative importance of so few species, specifically four sea-run species (cisco, whitefish, longnose sucker, brook trout), that together make up $95.9 \%$ of the catch at Fort George and $\mathbf{9 6 . 5 \%}$ at Eastmain in the near community areas.

Species composition appears relatively constant from year to year at a given location. The November/December Black's Island ice fishery, for example, consistently produced an almost uniform catch of cisco, $92 \%$ to 95\%, over three years (Table 5). As may be expected on general biological grounds, however, species composition varies from location to location and season to season. In the Fort George area, defined as the $15 \mathrm{~km}$ day-trip distance from the settlement, cisco was the most numerous fish, but its frequency varied from $39 \%$ of total catch in spring, $58 \%$ in summer, to $86.5 \%$ in the fall (Table 6).

TABLE 5. Species composition in Black's Island ice-fishery, Fort George.

\begin{tabular}{lcccccc} 
Dates & $\begin{array}{c}\text { No. of } \\
\text { net sets }\end{array}$ & Whitefish & Cisco & $\begin{array}{c}\text { Total no. } \\
\text { of fish }\end{array}$ \\
\hline $28 / 11-1 / 12,1975$ & 11 & 12 & $(4 \%)$ & 266 & $(95 \%)$ & 280 \\
$21 / 11-29 / 11,1976$ & 42 & 82 & $(8 \%)$ & 898 & $(92 \%)$ & 981 \\
$27 / 11-15 / 12,1977$ & 23 & 20 & $(4 \%)$ & 429 & $(94 \%)$ & 454
\end{tabular}

TABLE 6. Numbers of fish by season and by area, and percentage of Cisco and Whitefish in catches of the near Fort George area domestic fishery.

\begin{tabular}{lccc} 
& $\begin{array}{c}\text { Total catch by numbers, } \\
\text { all species }\end{array}$ & \%Cisco & \% Whitefish \\
\hline Spring & & & \\
Summer & 1,619 & 39.1 & 11.6 \\
Fall & 1,121 & 58.0 & 3.7 \\
& 2,963 & 86.5 & 10.1
\end{tabular}

Away from Fort George, whitefish dominated the catches, constituting 34\% of coastal samples and $49 \%$ of lake samples within Fort George traplines (Table 7). In some locations on the coast, brook trout is the most abundant species in spring. Table 7 also includes data collected from 62 inland waterbodies by Cree fishermen using traditional gear, mainly 4 inch gillnets but 10 inch nets for sturgeon. These samples, obtained in summer for a study of mercury in fish (Penn, 1978), were collected in Mistassini, Waswanipi and Nemaska trapline areas. Frequencies of less common species are probably over-represented in the samples because less than the entire catch for some of 


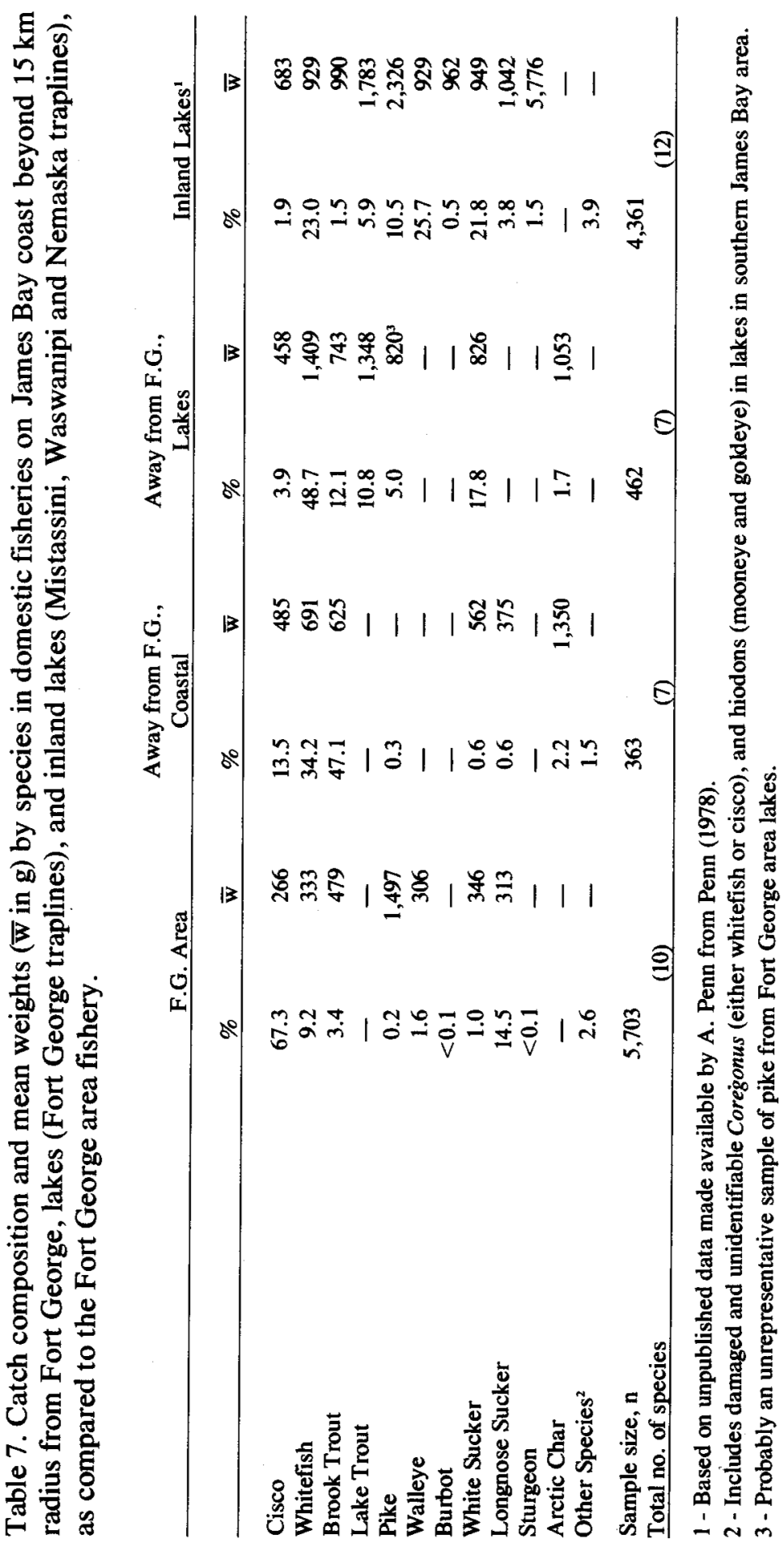


the more abundant species, such as whitefish and white suckers, were retained. Bearing in mind this limitation, these figures nevertheless represent the most comprehensive set of field data on the domestic fisheries of the interior James Bay area. Biological survey data for some parts of these territories may be found in Magnin (1977) and Magnin et al. (1973). The domestic catch inland consists of almost equal parts of whitefish, white suckers, walleye, and the combined total of other species. Within the total area, species composition varies by lake and by latitude; in particular, the trouts are absent or rare in Waswanipi and Nemaska areas.

Each of the fisheries summarized in Table 7 is based on a relatively small number of species, but the species composition differs. Cisco is important only on the coast, probably in the near-community estuarine areas of Eastmain, Paint Hills, Rupert House and Great Whale, as well as in Fort George. Whitefish of the James Bay Coast are of relatively small size compared to those in lakes, as first observed by Melville et al. (1915). This may be seen best by comparing the mean size of whitefish in the "away from Fort George" (beyond $15 \mathrm{~km}$ ) coastal fishery vs. lake fisheries. Some of the largest whitefish come from Cape Jones area lakes near the coast. The mean weight of $1,400 \mathrm{~g}$ for inland whitefish reflects this. Due to small sample sizes and small number of sampling locations (six in coastal and seven in lakes), the away from Fort George fisheries are not well represented. Nevertheless, the table provides sufficient evidence to indicate that Fort George area whitefish is unusually low in abundance (also compare with Eastmain, Table 4), and that the catch consists of undersized fish.

\section{BIOLOGY OF COREGONUS}

It is clear from the foregoing that the two species of Coregonus constitute the major fish resource in the eastern James Bay area. Biology of inland stocks of both species has been well studied in parts of the Canadian North. Coastal stocks, on the other hand, are poorly documented in the literature, even though a considerable amount of research has focussed on them recently on the James Bay coast. The following is a summary of biological information on coastal Fort George area whitefish and cisco.

Based on frequency of catches in the lower La Grande and estuary, both whitefish and cisco are present in the river at the time of ice break-up, spreading out into the estuary in early summer. In August, cisco move back up the river, probably followed by whitefish in September. These results are consistent with findings of tagging studies by Environment Canada and Société d'énergie de la Baie James (Turgeon, 1976) that both species migrate up to some $30 \mathrm{~km}$ north and some $8 \mathrm{~km}$ south of the river mouth in summer (see El-Sabh and Koutitonsky, 1977, for currents). Both species return in the fall to the area of the first rapids on La Grande, $37 \mathrm{~km}$ from the mouth of the river. According to Faubert (1975), both species spawn in the area below the rapids in mid to late October, peak of spawning occurring in water temperatures of about $1^{\circ} \mathrm{C}$. 
The Fort George area domestic fishery therefore appears to be based on one stock of each of the two species. As summarized in Table 8, age composition of these whitefish ranged from $3+$ to $9+$ years. Whitefish of $6+$ years was the most abundant year-class in the samples, but the samples

TABLE 8. Age and size composition of whitefish (Coregonus clupeaformis) and cisco $(C$. artedii) from the Fort George area. Dymond's (1933) data from the 1920's from James and Hudson bays are given for comparison. Lengths are mean \pm SD fork lengths, $\mathrm{mm}$.

\begin{tabular}{crcrlrrrr} 
Age & \multicolumn{2}{l}{ Whitefish } & \multicolumn{2}{c}{ Cisco } & \multicolumn{2}{c}{$\begin{array}{c}\text { Whitefish } \\
\text { (Dymond 1933) }\end{array}$} & \multicolumn{2}{c}{$\begin{array}{c}\text { Cisco } \\
\text { (Dymond 1933) }\end{array}$} \\
An & N & length & N & length & N & length & N & length \\
$2+$ & 0 & - & 0 & - & 2 & 194 & 4 & 202 \\
$3+$ & 3 & $238 \pm 10$ & 3 & $225 \pm 18$ & 22 & 223 & 10 & 236 \\
$4+$ & 10 & $265 \pm 31$ & 30 & $248 \pm 31$ & 6 & 266 & 5 & 309 \\
$5+$ & 22 & $307 \pm 32$ & 60 & $290 \pm 35$ & 9 & 286 & 10 & 317 \\
$6+$ & 37 & $366 \pm 42$ & 41 & $328 \pm 35$ & 4 & 321 & 9 & 335 \\
$7+$ & 28 & $400 \pm 32$ & 17 & $338 \pm 24$ & 9 & 347 & 17 & 354 \\
$8+$ & 14 & $402 \pm 37$ & 3 & $328 \pm 18$ & 1 & 391 & 6 & 367 \\
$9+$ & 3 & $418 \pm 66$ & 0 & - & 2 & 396 & 0 & -
\end{tabular}

probably under-represented small whitefish caught in $2 \frac{1}{2}$ inch nets in the fall fishery. Three-year-old whitefish were $238 \pm 10 \mathrm{~mm}$ fork length (tip of nose to the fork of the tail), nine-year-olds, $418 \pm 66 \mathrm{~mm}$. Three-year-old cisco were $225 \pm 18 \mathrm{~mm}$ and eight-year-olds $328 \pm 18$; cisco of $5+$ years was the most abundant year-class in the samples. Table 8 also shows, for comparison, Dymond's (1933) data collected from James and Hudson bays about half a century before the present study. The whitefish in the present study are somewhat larger and the cisco somewhat smaller.

In late spring and summer, $50 \%$ of all Fort George stock cisco over $260 \mathrm{~mm}$ $(\mathrm{N}=166)$ and whitefish over $350 \mathrm{~mm}(\mathrm{~N}=47)$ were mature. Thus, cisco had four reproductive year-classes $(4+, 5+, 6+, 7+)$ and whitefish three $(6+, 7+$, $8+$ ). As suggested earlier (Berkes, 1977), the use of the $2 \frac{1}{2}$ inch net, while optimizing cisco catches, probably has a serious effect on whitefish by the removal of immature whitefish as an incidental catch.

The simplified age-class structure of whitefish, the small mean size, and relative scarcity in the near Fort George harvests all indicate that the lower La Grande stock of whitefish is overfished.

One implication of this finding for management of domestic fisheries is that non-commercial fishermen of a community which is small by Southern standards (but large by Northern standards) are capable of overfishing some stocks. The second practical implication is related to the James Bay hydro project. Environmental stresses brought about first by diversions of river flow for filling of reservoirs, and secondly by post-management river flow and temperature regimes, may be expected to affect the whitefish stock more (because the fishing stress is relatively greater) than they would the cisco stock. This is a testable hypothesis the investigation of which awaits the execution of the hydro project. 


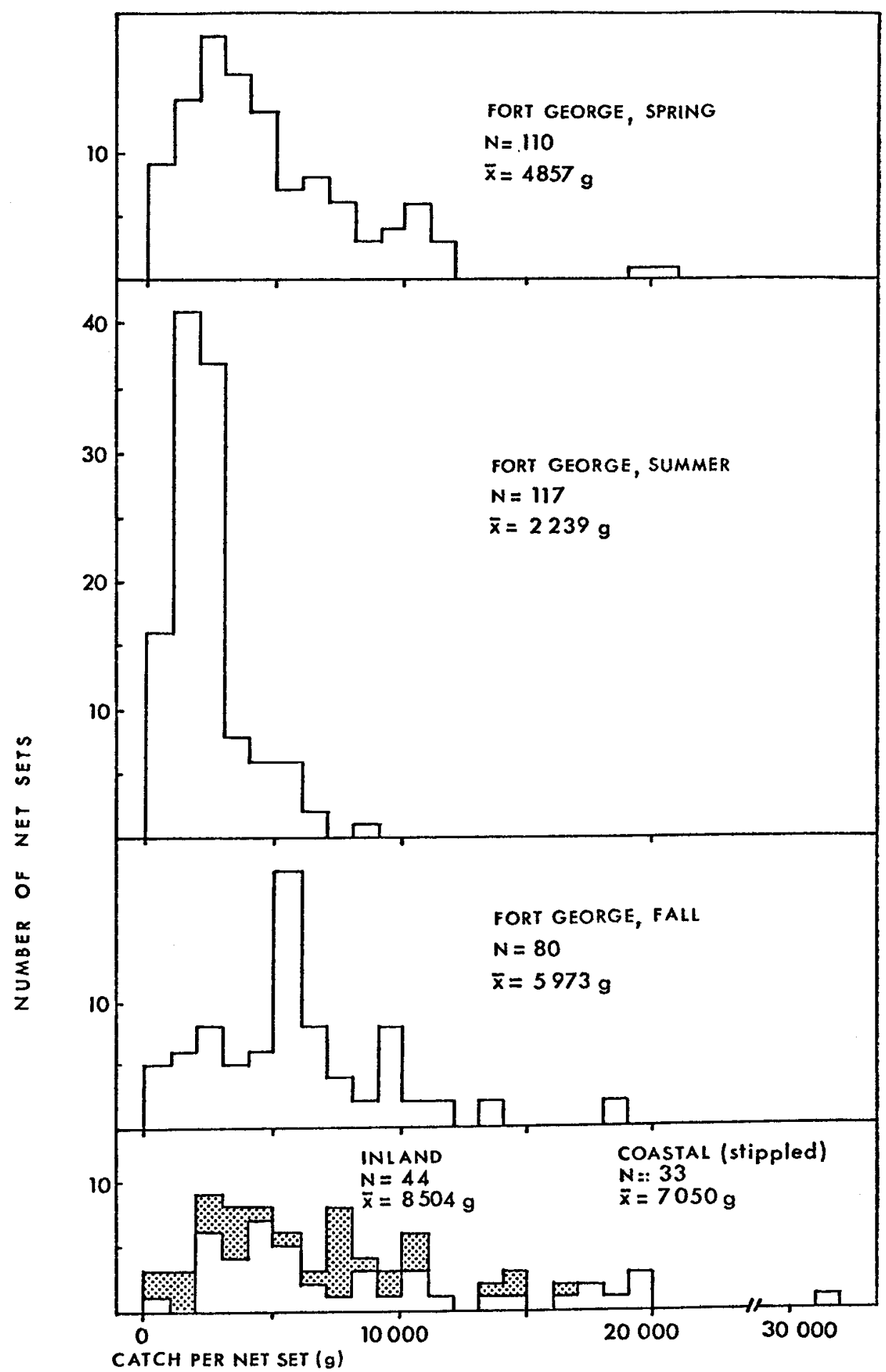

FIG. 2. Frequency of catch per net set (about $50 \mathrm{~m}$ nets), various mesh sizes, in Fort George domestic fisheries. 
Figure 2 shows the variation in catch per net set in the three seasons of the near Fort George gillnet fishery and coastal and lake fisheries beyond a 15 $\mathrm{km}$ radius from the settlement. In the Fort George area, spring and fall catches were moderately high, with (arithmetic) means of $4,857 \mathrm{~g}$ and $5,973 \mathrm{~g}$ per net set, respectively. Summer (late July and August) catches were lower, with a mean of $2,239 \mathrm{~g}$. Generally higher catches were obtained on the coast beyond the day-trip distance of $15 \mathrm{~km}, 7,050 \mathrm{~g}$ and in lakes, 8,504 $\mathrm{g}$ per net set. Frequency distribution of catches tend to be skewed to the left, the mode being lower than the arithmetic mean.

Since the fishing success of more experienced and serious fishermen is thought to be generally higher than that of others, it is of interest to investigate the degree of variability in fishing success among fishermen. This is done in Table 9. The total number of net sets recorded in Table 9 (159) is about double the number of days fishing (81), which is similar to the overall number of net sets per day $(1.9 \pm 1.2)$ in the study showing that the data in Table 9 are representative.

In three of the four sets of data, the most successful fishermen caught twice as much as the least successful fishermen. This holds whether the catch per effort is defined by catch per day or catch per set. The greatest variation occurred in Cape Jones area samples where the most successful fisherman caught about seven times as much, per day and per net set, as the least successful fisherman. At Cape Jones, fishermen were exploiting a number of adjacent water bodies within a day's travel from a base camp; in this relatively heterogeneous environment, it is presumably the knowledge of good fishing areas which permitted unusually good catches.

Data from the November ice-fishery, for three years, show that one fisherman does not necessarily obtain consistently larger catches than another. Further, catches in different years for one fisherman tend to be similar; this is shown also by catch records from the Capsaouis River mouth, where fisherman A obtained a greater catch per day in year II than in year I by virtue of setting more nets. His catch per net set, however, was almost constant.

If the data in Table 9 are representative of the fishery, it appears that individual variation in fishing success at a given time and place falls within a relatively narrow range. In three cases out of four, there is only a two-fold difference between the highest and the lowest individual catches per unit of effort, or a $\pm 33 \%$ variation around the mean.

\section{PRODUCTIVITY OF FISHING IN PERSPECTIVE}

Two issues are addressed here. The first is the comparison of productivity of fishing with the productivity of other harvesting activities. The second is the comparison of productivity of fish harvesting on a subsistence basis, with the productivity of commercial fisheries, a potentially competing use for the same resource. 
TABLE 9. Variation in fishing success. Data from comparable times and locations. Catches are whole weights, $g$.

\begin{tabular}{cccc}
$\begin{array}{c}\text { No. of } \\
\text { days } \\
\text { fishing }\end{array}$ & $\begin{array}{c}\text { No. of } \\
\text { net } \\
\text { sets }\end{array}$ & $\begin{array}{c}\text { Total } \\
\text { catch }\end{array}$ \\
\hline
\end{tabular}

Lower Eastmain Riv., late Aug.

fisherman A

B
C
D
E$$
5
$$$$
5
$$$$
5
$$$$
\mathbf{E}
$$

3
3

catch

Catch

per

catch per

day

net set

Black's Island, Fort George,

late Nov.

fisherman $A$ year I

$$
\begin{aligned}
& \text { B year I } \\
& \text { A year II } \\
& \text { B year II } \\
& \text { A year III }
\end{aligned}
$$

56,645

18,630

18,815

8,380

14,730

11,329

3,726

3,763

2,793

4,910

5,664

3,726

3136

2,793

2,455

Capsaouis Riv., north of Fort

George, early June

fisherman A year I

$$
\begin{aligned}
& \text { B } \\
& \text { C } \\
& \text { A year II } \\
& \text { D }
\end{aligned}
$$

$\begin{array}{rr}4 & 8 \\ 2 & 3 \\ 9 & 18 \\ 8 & 24 \\ 9 & 23\end{array}$

44,105

19,590

124,520

96,570

113,975

11,026

9,795

13,836

12,094

12,664

5,513

6,530

6,918

4,031

4,955

Cape Jones area lakes, early

July

fisherman $A$

$$
\begin{aligned}
& \text { B } \\
& \text { C } \\
& \text { D }
\end{aligned}
$$

$\begin{array}{ll}2 & 2 \\ 2 & 2 \\ 2 & 3 \\ 3 & 5 \\ 2 & 4\end{array}$

23,665

22,825

19,800

52,830

34,100

11,832

11,412

9,900

17,610

17,050

11,832

11,412

6,600

10,566

8,525

20,162 
Feit (1973) studied the yield per effort of different types of animal resources harvested by Waswanipi Cree hunters. He found that the seasonal yield per effort was highest in moose hunting, followed by beaver trapping, fishing and small game hunting, in that order. Moose provided a return ranging over $100,000 \mathrm{kcal}$ or about $80 \mathrm{~kg}$ (assuming $124 \mathrm{kcal} / 100 \mathrm{~g}$ ) per man-day of work, beaver provided seasonal averages of 16,000 to $24,000 \mathrm{kcal}$ or $10-15 \mathrm{~kg}$ (assuming $158 \mathrm{kcal} / 100 \mathrm{~g}$ ), fish $10,000 \mathrm{kcal}$ or $8 \mathrm{~kg}$ (assuming $126 \mathrm{kcal} / 100 \mathrm{~g}$ ). Feit (1973) furthermore found that the order of harvesting preferences of the Waswanipi Cree closely paralleled this order. In terms of biological productivity, however, Feit (1973) estimated fish and small game to have greater potential than the other two resources. Thus, he argued, fish and small game such as hare provided a backup resource, hunting preference going to big game and beaver whenever those resources were available.

By contrast to Waswanipi or Mistassini, in Fort George and other coastal communities the major harvest resource is waterfowl, in particular the Canada goose (Branta canadensis). Fort George hunters on the average harvested 148 waterfowl, 70 of them Canadas, total of both spring and fall hunts in 1974-75 (JBNQNHRC, 1976). They obtained 5.1 waterfowl totalling $11.5 \mathrm{~kg}$ whole weight per man-day of hunting (JBNQNHRC, 1976: 136, Appendix: 154). This rate of return is, on the average, more than twice as high as the fish catch per man-day in the present study. JBNQNHRC (1976) estimated the edible fraction of waterfowl to be $70 \%$ by weight, the same as that of fish. Even though these results are not strictly comparable with Feit's (1973) because of differences in research techniques, they demonstrate the general usefulness of his theory.

Productivity of other species groups in the Fort George harvest cannot be determined with any degree of reliability, but comparison of the waterfowl catch per unit of effort with that of fish provides some useful generalizations. Fort George hunters/fishermen prefer waterfowl hunting to fishing during the limited time the resource is available at times of seasonal migrations. This is not to say that fishing entirely ceases in April/May and September, the goose months, but certainly becomes a minor activity. However, during summer when no other major animal group is available, fishing becomes the major focus of harvesting. As the catch per effort decreases in mid-summer in the Fort George area (Fig. 2), there is a choice of two harvesting strategies: some fishermen establish camps in lakes or on the coast where the catch per effort is higher; others compensate for the decreasing catch per effort by increasing the fishing effort, that is, the number of nets set. The latter phenomenon, documented elsewhere (Berkes, 1977), is important in qualifying that the supposed lower limit of prey abundance for exploitation, similar to "feeding thresholds" well known to animal ecologists and sometimes applied to human ecology (Macaulay and Boag, 1974), is not a fixed point but a variable limit. A Fort George Cree person may be willing to go fishing in mid-summer for yields as low as about $2 \mathrm{~kg}$ per net set if there is no other game and no wage employment available; he will still "get what he needs" by setting more nets so that his daily catch remains high. Thus, deterministic models of feeding thresholds as used in animal ecology are of limited use in human ecology. 
In many areas in the North during the 1950's and 1960's, commercial fisheries were established by the Canada Department of Indian and Northern Affairs. While some information exists on the catch levels of these fisheries (Power et Le Jeune, 1976, for the James Bay area), relationships between commercial fishing and subsistence fishing were not studied. There have been some notable exceptions elsewhere (Rogers, 1972). It is probably safe to say that there has been an implicit assumption that domestic fisheries are inefficient and produce little.

This assumption appears to hold if efficiency is defined in terms of catch per day or catch per fisherman. The catch by Fort George fishermen between freeze-up and break-up is about $36,000 \mathrm{~kg}$ edible weight, estimated on the basis of two-thirds of total annual catch for 1973/74 (Weinstein, 1976); at least half of this catch would be Coregonus. The number of fishermen participating in the fishery may be about 200 , giving $180 \mathrm{~kg}$ per fisherman. By contrast, the average catch in the Lake Winnipeg summer fishery, for example, is 5,000-7,000 kg dressed weight of whitefish per fisherman (Davidoff $e t$ al., 1973, Table 4).

However, if efficiency of harvesting is compared on the basis of catch per unit length of net set, then results are quite different. The total community fishing effort at Fort George may be estimated from questionnaire data collected by JBNQNHRC (1976). This study projected a total of 14,693 net-days between break-up and freeze-up. This total divided by 150 days (five months between break-up and freeze-up) gives an average of 100 nets set by the entire community on any one given day, for a total community fishing effort of about 5,000 m. By comparison, each commercial fisherman in Lake Winnipeg is licensed to set 7,312 $\mathrm{m}$ of 5 inch gillnets (Davidoff et al., 1973). Furthermore, these are three or four times as wide as those used in the Fort George fishery.

On a length of net set basis, therefore, the Fort George domestic fishery obtains about six times more fish than the Lake Winnipeg commercial fishery, not taking into account the width of the nets used. This does not mean to say that a whole village of fishermen setting some $100 \mathrm{~m}$ of nets each can be replaced by one full-time effort-intensive fisherman setting $5,000 \mathrm{~m}$ of nets: that probably would not work for two reasons. First, the "secret" of Fort George subsistence fishermen is in the skillful use of low-intensity fishing in a flexible manner carefully tuned to the characteristics of the local aquatic system (Berkes, 1977). Secondly, to interpret fishing solely as a means of obtaining so many kilograms of fish flesh and to give it a cash value would be objectionable to most Cree, as fishing is considered a way of life.

\section{CONCLUSIONS}

\section{Implications for Resource Planning}

Fish have provided a staple or a back-up resource in the eastern James Bay area in historical times, and the large potential of the resource has long-term importance for the people of the area. Most stocks of fish are lightly utilized at present. In the vicinity of population centres, however, some species may 
already be overfished. In the area as a whole, there is biological potential to sustain a larger catch.

There are two resource planning implications of this. First, the total catch may be increased by distributing the harvesting effort more evenly over a larger area, rather than by intensifying harvests in areas already fished heavily. Large differences in catch per unit effort in the immediate area of Fort George as compared to that in more remote locations (Fig. 2) is in support of this conclusion.

Secondly, it must be recognized that there is a certain critical size for a northern community, given its location, transportation facilities and available resources, beyond which the accessible hunting/fishing area will not support that population. It appears that in the past two decades or so, availability of more efficient harvesting technology helped increase the accessible hunting/fishing area, and therefore compensated for the negative effect of concentrating the native population in permanent settlements. But it has also made hunters/fishermen increasingly more dependent on cash for the purchase of equipment such as large canoes and outboard motors.

Part-time hunting and fishing, harvesting during seasonal abundance of game, and short daily trips from the settlement may all be considered adaptations of the subsistence economy to settlement living. At Fort George, the use of large canoes with outboard motors makes it possible on a day-trip basis to harvest the entire La Grande River estuary, a zone which is biologically productive in comparison to adjacent waters but which is also harvested more intensely. This general finding is consistent with other studies, suggesting strongly that the use of new hunting technology in the North results in more efficient and extensive harvesting, rather than necessarily leading to an increase of catch or waste of resources. Freeman (1974/75) documented this for walrus hunting in Southampton Island, and Usher (1972) for trapping in Banks Island.

There are certain limits, however, beyond which these adaptations will not be sufficient to maintain large bush harvests. With increasing population growth and sedentarization, Fort George may be reaching one of these limits in the form of depletion of whitefish in the immediate area of the settlement. Similarly, Brody (1977) writes that Frobisher Bay (pop. 900), the largest Inuit settlement in the eastern Arctic, is always short of country foods, even seal meat. The appearance of a semi-permanent camp not far from Frobisher Bay but closer to good hunting grounds (M. Curtis, pers. comm.) may be indicative of a general trend for large northern settlements. In the case of Fort George,possible damage to resources due to the hydro project and the necessary relocation of the settlement, about eight $\mathrm{km}$ upriver, will create new problems the solution of which will have to take into account the desire of many people to continue hunting and fishing on the coast. Certain provisions of the James Bay and Northern Quebec Agreement, such as the hunters' income security program and the principle of guaranteed levels of native harvest, take on added significance for the solution of these problems. 
Spokesmen for the James Bay Cree people have argued that it is desirable to continue a hunting/fishing/trapping way of life as part of a mixed economy (see JBNQA, 1975). It has also been argued that it is desirable to produce locally much of the food, especially protein (Berkes and Farkas, 1978). Given these assumptions, basically two things are needed: available resources, and cash for transportation and for purchase of harvesting equipment. A large settlement often has greater opportunities for wage employment than a small community, but as in the case of Frobisher Bay (Brody, 1977), this by itself may not be sufficient to satisfy local aspirations for hunting and requirements for bush meat. Clearly, a balance is required between size of the settlement and biological productivity of harvestable resources in the area accessible to it. Siting is crucially important in this regard.

Also important is an adequate cash income for outfitting; as shown for other areas in the North (Nowak, 1975). Certainly renewable resources have a role to play for creation of employment and income. Fish probably provide a larger potential resource base for local renewable resource development than to do other major wildlife groups such as big game, waterfowl and fur animals. In the James Bay area, prospects are good for both recreational fishing and commercial fishing for local markets. However, subsistence fishing at present has priority over other uses of the resource. This is the preference of the Cree people as recognized by the Agreement and also recommended by Berger (1977: 117) for the Mackenzie area. In practice this means that sport and commercial fisheries should be carefully located to avoid conflict with subsistence fisheries and to have the fishing effort distributed over a large area.

Given these constraints, it is not easy to forecast development trends for sport fisheries. The area is very lightly developed at present and no studies have been made on the market demand. If growth rates may be similar to those in the NWT, however, rapid development of recreational fisheries may be expected in the early 1980's. This provides a unique chance for sport fishery resource development planning in the late 1970's, with the participation of the local native population (Berkes, 1978).

Commercial fisheries organized in the 1950's and the 1960's were mostly oriented for Southern markets, with low returns for native fishermen. As more people are being engaged in wage economy in the James Bay area, a local market is now developing for native-run commercial fisheries. Some species of fish are being sold for the first time in local cooperative stores, not only in Fort George but also in medium-size communities such as Paint Hills (Wemindji). A major problem for commercial fisheries is the presence of high mercury levels throughout the James Bay area. Mercury in commercial-size specimens of pike and walleye (and probably lake trout) almost always exceeds the Canadian government standard of $0.5 \mathrm{ppm}$ mercury; in other species, including whitefish, it is almost always lower than this (Delisle, 1977; Penn, 1978). It was the question of mercury levels that caused, in 1970, the shutdown of Cree commercial fisheries in southern James Bay which employed 200 men and earned about $\$ 400,000$ a year. 
Nevertheless, the experience in the 1960's in the Waswanipi area showed that commercial fisheries can be made compatible with the Cree way of life, with flexibility in seasons and working hours, and with an opportunity to engage the whole family in the operation (LaRusic, 1968). Similarly, guiding for hunting and fishing has generally been regarded by the Cree to provide desirable jobs. Recreational fishing may provide particularly attractive jobs, especially if it is designed to attract people interested in a "fuller experience of nordicity" (Regier, 1976), rather than "trophy types" and if "it can provide an incentive to native people to maintain their traditional skills" (Power and Le Jeune, 1976). These considerations lead to a conclusion in support of Berger's (1977) call for local economic development based on renewable resouces, including food processing and service industries associated with recreational fishing.

\section{A Biological Management Principle}

Unlike domestic fisheries, commercial fisheries are subject to government regulation. If native commercial fisheries develop in the eastern James Bay area in the coming years, they will probably be subject to regulations comparable to those elsewhere in the North. However, existing commercial fishery regulations in many places in the North have not been working well. Healey (1975), for example, argued that the use of large gillnet mesh sizes (51/2 inch) in the Great Slave Lake has led to the selective removal of older year-classes of whitefish, thus reducing population resilience, but without triggering population compensatory responses such as increased growth rates and lowered age at maturity. His argument, therefore, suggested the use of smaller mesh sizes.

It is well known that ecological characteristics of northern fish populations are different from those of more familiar north-temperate populations, suggesting that different exploitation strategies may be in order (Johnson, 1976). Fishery science has borrowed one technique from traditional native fisheries: rotation of fishing areas, relatively heavy exploitation followed by several years of non-exploitation which, in Johnson's (1976) words, is sound management for slow growing climax populations. At present, the Cree practice rotation of fishing, hunting and trapping areas in inland areas of the James Bay region (Feit, 1973).

There is another practice that should perhaps be examined for use in commercial fisheries. In the Fort George area on the James Bay coast and lakes close to the coast, the domestic fishery exploits the resource, mainly whitefish, by the use of a mix of gillnet mesh sizes, 3, 31/2, 4 and 5 inch nets (Table 3). Age structures of fish caught under this strategy are not available to test if there may be population compensatory responses, but whitefish are caught in relatively large numbers (Table 7) and the catch per effort is high (Fig. 2) suggesting that this may be an ecologically viable strategy for harvesting whitefish. It should be remembered, however, that fishing intensity is low compared to that of commercial fisheries.

The Fort George domestic fishery contrasts sharply, therefore, with that of northern commercial fisheries: at Fort George, a mix of mesh sizes is used, 
together with a low fishing intensity; in northern commercial fisheries a single large mesh size is used, together with a high fishing intensity.

The Fort George practice suggests a testable management principle which may be stated thus: the harvest of more year-classes at a lower rate than presently practiced in northern commercial fisheries, is likely to stimulate population compensatory responses, without leading to a selective removal of the older year-classes which would reduce population resilience and increase the probability of a population crash.

In suggesting the use of smaller mesh sizes for the Great Slave Lake fishery, Healey (1975) did not comment on the fishing effort. Clearly, the principle stated here would work only if the fishing intensity (the total length of gillnets used) is low, to prevent fishing out the entire population. Reduction of fishing intensity would not necessarily result in a lower yield; rather, the efficiency (catch per length of net) is likely to go up because a much larger part of the population biomass is available to a mix of small, medium and large mesh sizes than to one large mesh size alone, as graphically shown by Healey (1975, Fig. 6). An immediate implication of this for northern fishery management policies is a change of emphasis from primarily regulating the mesh size to regulating the fishing intensity.

\section{ACKNOWLEDGEMENTS}

The study was made possible by the cooperation of local band governments, the Grand Council of the Crees (of Quebec), many fishermen in Fort George and Eastmain and their families, and numerous other people who contributed to my understanding of Cree subsistence fisheries. R. Baxter, J. Bobbish, H. Dunlop, S. Herodier and R. Polson provided technical assistance. For useful information and comments, I thank $\mathbf{J}$. Bobbish, M. Chapman, R. Cuciurean, M. Curtis, H. Feit, T. Morantz Ornstein, A. Penn, G. Power and G. Speers. The study was supported by the National Research Council of Canada.

\section{REFERENCES}

BERGER, T.R. 1977. Northern Frontier, Northern Homeland. Volume Two. Ottawa: Supply and Services Canada.

BERKES, F. 1977. Fishery resource use in a subarctic Indian community. Human Ecology, 5: 289-307.

- 1978. Management of recreational fisheries in northern Quebec: policies versus tools. Canadian Public Policy, 4: 460-473.

_ and FARKAS, C. S. 1978. Eastern James Bay Cree Indians: Changing patterns of wild food use and nutrition. Ecology of Food and Nutrition, 7: 155-172.

BLISS, L. C. 1978. The report of the Mackenzie Valley pipeline inquiry, Volume two: an environmental critique. Musk-Ox, 21: 34-38.

BRODY, H. 1977. Industrial impact in the Canadian North. Polar Record, 18: 333-339.

DAVIDOFF, E. B., RYBICKI, R. W, and DOAN, K. H. 1973. Changes in the populations of lake whitefish (Coregonus clupeaformis) in Lake Winnipeg from 1944 to 1969. Journal of the Fisheries Research Board of Canada, 30: 1667-1682.

DELISLE, C. E. 1977. Contamination par le mercure de l'environement biologique et physique du nord-ouest Québécois. Canadian Society of Environmental Biologists, Bulletin, 34(3): 63-83.

DYMOND, J. R. 1933. Biological and oceanographic conditions in Hudson Bay. 8. The Coregonine fishes of Hudson and James bays. Contributions to Canadian Biology and Fisheries, 8 (N.S.) No. 28: $1-12$.

EL-SABH, M. I. amd KOUTITONSKY, v. 1977. An oceonographic study of James Bay before the completion of the La Grande hydroelectric complex. Arctic, 30: 169-186. 
ELtoN, C. S. 1942. Voles, Mice and Lemmings. Problems in Population Dynamics. London: Oxford Univer. Press.

FAUBERT, N. 1975. Etude spéciale du corégone anadrome des rivières Eastmain et La Grande Rivière, 1974. Rapports d'Expédition, No. 39. Montréal: Société d'énergie de la Baie James.

FEIT, H. A. 1973. The ethno-ecology of the Waswanipi Cree; or how hunters can manage their resources. In: B. Cox (Ed.), Cultural Ecology. Toronto: McClelland and Stewart. p. 115-125.

FREEMAN, M.M.R. 1969. Development strategies and indigenous people in the Canadian Arctic. In: Intermediate Adaptation in Newfoundland and the Arctic: A Strategy of Social and Economic Development. Newfoundland Social and Economic Papers No. 4. St. John's: Memorial University of Newfoundland.

- 1974/75. Studies in maritime hunting. II. An analysis of walrus hunting and utilization: Southampton Island, N.W.T. 1970. Folk, 16-17:147-158.

HEALEY, M.C. 1975. Dynamics of exploited whitefish populations and their management with special reference to the Northwest Territories, Journal of the Fisheries Research Board of Canada, 32:427-448.

HELM, J. and LURIE, N. O. 1961. The subsistence economy of the Dogrib Indians of Lac LaMartre in the MacKenzie District of the N.W.T. Indian and Northern Affairs, Northern Research Division NCRC-61-3, $117 \mathrm{pp}$.

JBNQA 1975. The James Bay and Northern Quebec Agreement. Québec: Editeur Officiel du Québec.

JBNQNHRC 1976. Research to establish present levels of harvesting by native peoples of Northern Quebec. Part I. A report on the harvests by the James Bay Cree. Montreal: James Bay and Northern Quebec Native Harvesting Research Committee. 2 Vols.

JOHNSON, L. 1975. The Great Bear Lake: Its place in history. Arctic, 28:231-244. 1976. Ecology of arctic populations of lake trout, Salvelinus namaycush, lake whitefish, Coregonus clupeaformis, arctic char, S. alpinus, and assorted species in unexploited lakes of the Canadian Northwest Territories. Journal of the Fisheries Research Board of Canada, 33:2459-2488.

KERR, A.J. 1950. Subsistence and social organization in a fur trade community. Anthropological Report on the Ruperts House Indians. Presented to National Committee for Community Health Studies, Ottawa.

KIDD, B. T., GREENDALE, R., MORIN, R., BAXTER, R. and POWER, G. 1975. Interim report of James Bay Project Study by the Arctic Biological Station. M.S. Report. Environment Canada. 267 p.

LARUSIC, I.C. 1968. From hunter to proletarian: the involvement of Cree Indians in the white wage economy of central Québec. In: ARDA Project No. 34002, Final Report, Annex 2, Ottawa.

LEBUIS, F. 1971. Le complexe culturel de la pèche de subsistance à Némiska, au Nouveau-Québec. Thèse de maitrise, départment d'Anthropologie, Université de Montreal.

MACAULAY, A. J. and BOAG, D. A. 1974. Waterfowl harvest by Slave Indians of Northern Alberta. Arctic, 27:15-26.

MAGNIN, E. 1977. Ecologie de Eaux Douces du Territoire de la Baie James. Société d'énergie de la Baie James. Montreal. 454 pp.

MAGNIN, F., LEGENDRE, V. and MURAWSKA, E. 1973. Croissance de 11 espèces de poissons de la région de Waswanipi, centre ouest du Québec. Ministère du Tourisme, de la Chasse et de la Pêche, Service de la Faune, Rapport No. 8:13-43.

MELVILLE, C. D., LOWER, A. R. M. and COMEAU, N. A. 1915. Reports on Fisheries investigations in Hudson and James Bays and tributory waters in 1914. Ottawa: Department of the Naval Service.

MOUSETTE, M. 1973. La pêche au filet maillant chez les Indiens de l'est du Canada. Recherches amérindiennes au Québec, 3:41-67.

NOWAK, M. 1975. Subsistence trends in a modern Eskimo community. Arctic, 28:21-34.

PENN, A.F. 1975. Development of James Bay: the role of environmental impact assessment in determining the legal right to an interlocutory injunction. Journal of the Fisheries Research Board of Canada, 32:136-160.

- 1978. The Distribution of mercury, selenium and certain heavy metals in major fish species from northem Quebec. A report on the screening programme for mercury in fish: Mistassini and Waswanipi regions. Prepared for Fisheries and Environment Canada. Montreal.

POWER, G. et LE JEUNE, R. 1976. Le potential de pêche du Nouveau-Québec. Cahiers de Géographie de Québec, 20:409-428.

REGIER, H.A. 1976. Science for the scattered fisheries of the Canadian interior. Journal of the Fisheries Research Board of Canada, 33:1213-1232.

ROGERS, E.S. 1963. The hunting group-hunting territory complex among the Mistassini Indians. National Museums of Canada, Bull. No. 195:95 p. 
1972. Ojibwa Fisheries in Northwestern Ontario. Division of Fish and Wildlife, Ontario Ministry of Natural Resources, Toronto. $49 \mathrm{pp}$.

, 1973. The Quest for Food and Furs. The Mistassini Cree, 1953-54. National Museums of Canada, Publications in Ethnology, No. 5:83 pp.

, and BLACK, M. B. 1976. Subsistence strategy in the fish and hare period, northern Ontario: The Weagamow Ojibwa, 1880-1920. Journal of Anthropological Research, 32: 1-43.

STABLER, J.C. 1977. The report of the Mackenzie Valley pipeline inquiry, Volume I: A socio-economic critique. Musk-Ox, 20:57-65.

TURGEON, M. 1976. Etude des poissons anadromes des rivières Eastmain et La Grande Riviére. Rapports d'Expédition No. 64. Montréal: Société d'énergie de la Baie James.

USHER, P.J. 1972. The use of snowmobiles for trapping on Banks Island. Arctic, 25:171-181.

WEINSTEIN, M.S. 1976. What the land provides. An examination of the Fort George subsistence economy and the possible consequences on it of the James Bay hydroelectric project. Report of the Fort George Resource Use Study.Montreal: Grand Council of the Crees (of Quebec). $255 \mathrm{p}$. 